\title{
Recent Insights into Aeromonas salmonicida and Its Bacteriophages in Aquaculture: A Comprehensive Review
}

\author{
Seon Young Park ${ }^{1,2 \dagger}$, Jee Eun Han ${ }^{3 \dagger}$, Hyemin Kwon ${ }^{1}$, Se Chang Park ${ }^{4 *}$, and Ji Hyung Kim ${ }^{1,5 *}$ \\ 'Infectious Disease Research Center, Korea Research Institute of Bioscience and Biotechnology, Daejeon 34141, \\ Republic of Korea \\ ${ }^{2}$ Division of Animal and Dairy Sciences, College of Agriculture and Life Science, Chungnam National University, \\ Daejeon 34134, Republic of Korea \\ ${ }^{3}$ Laboratory of Aquatic Biomedicine, College of Veterinary Medicine, Kyungpook National University, Daegu, \\ 41566, Republic of Korea \\ ${ }^{4}$ Laboratory of Aquatic Biomedicine, College of Veterinary Medicine and Research Institute for Veterinary Science, \\ Seoul National University, Seoul 08826, Republic of Korea \\ ${ }^{5}$ Department of Biomolecular Science, KRIBB School of Bioscience, Korea University of Science and Technology \\ (UST), Daejeon 34141, Republic of Korea
}

Received: May 25, 2020 Accepted: August 11, 2020

First published online: August 14, 2020

*Corresponding authors J.H.Kim

Phone: +82-42-879-8272 Fax: +82-42-879-8498

E-mail: kzh81@kribb.re.kr S.C.Park

Phone: +82-2-880-1282

Fax: +82-2-880-1213

E-mail: parksec@snu.ac.kr

${ }^{\dagger}$ These authors contributed equally to this work.

pISSN 1017-7825 eISSN 1738-8872

Copyright(C) 2020 by The Korean Society for Microbiology and Biotechnology
The emergence and spread of antimicrobial resistance in pathogenic bacteria of fish and shellfish have caused serious concerns in the aquaculture industry, owing to the potential health risks to humans and animals. Among these bacteria, Aeromonas salmonicida, which is one of the most important primary pathogens in salmonids, is responsible for significant economic losses in the global aquaculture industry, especially in salmonid farming because of its severe infectivity and acquisition of antimicrobial resistance. Therefore, interest in the use of alternative approaches to prevent and control $A$. salmonicida infections has increased in recent years, and several applications of bacteriophages (phages) have provided promising results. For several decades, A. salmonicida and phages infecting this fish pathogen have been thoroughly investigated in various research areas including aquaculture. The general overview of phage usage to control bacterial diseases in aquaculture, including the general advantages of this strategy, has been clearly described in previous reviews. Therefore, this review specifically focuses on providing insights into the phages infecting $A$. salmonicida, from basic research to biotechnological application in aquaculture, as well as recent advances in the study of $A$. salmonicida.

Keywords: Aeromonas salmonicida, antimicrobial resistance, salmonid culture, bacteriophage

\section{Introduction}

The genus Aeromonas (phylum, Proteobacteria; class, $\gamma$-Proteobacteria; order, Aeromonadales; and family, Aeromonadaceae) comprises a collection of ubiquitous gram-negative bacilli that are widespread in aquatic environments [1]. The taxonomy of this genus is in a continual state of flux as new species are identified by phenotypic and genotypic classifications, and the re-descriptions of the existing taxa are still in progress [2]. In a broad point of view, the genus Aeromonas could be divided into motile and non-motile species [3], and a total of 31 species are currently described in the genus [4]. Several motile Aeromonas species are known as pathogens of aquatic animals, and interest in this genus has recently increased due to its zoonotic potential [3]. Although the mode of transmission of these pathogens is not clearly understood, some Aeromonas species (e.g., A. hydrophila, A. caviae, A. dhakensis, and A. veronii biovar. sobria) have been recognized as causative agents of human diseases, including gastroenteritis, soft tissue infections, septicemia, peritonitis, pneumonia, and diarrhea [5-9]. Interest in the genus has also increased owing to the emergence of Aeromonas isolates that are resistant to commercial antibiotics commonly used in aquaculture and veterinary practice (e.g., $\beta$-lactams, tetracyclines, and quinolones) $[5,10-12]$.

Aeromonas salmonicida, which is known as the only non-motile species in the genus Aeromonas, is a primary fish pathogen that causes furunculosis in wild and cultured salmonids as well as bacterial septicemia in a broad variety of fish [13]. From the first findings in the 19th century [14], the species has been considered one of the main bacterial pathogens responsible for significant economic losses in the global aquaculture industry, especially in salmonid culture systems [13]. Previously, this species was thought to be a primary pathogen only in fishes; 
however, several recent reports have provided evidence on its zoonotic potential [15-17]. Although several antimicrobials and vaccines have been used to prevent or control the onset of disease outbreak in aquaculture [18, 19], furunculosis still occurs as a result of antimicrobial resistance (AMR) or vaccination failure [20, 21]. The emergence and prevalence of AMR in A. salmonicida against commercialized antibiotics, such as tetracycline and quinolones, has led to serious concern in the aquaculture industry due to the potential health risks to humans and animals [22-25]. Therefore, interest in alternative approaches that can prevent and control A. salmonicida infections has increased in recent years [26].

Bacteriophages (phages) are viruses that solely infect prokaryotic cells, and they are the most abundant living entities on earth [27]. With the global emergence of AMR bacteria, phages have received attention owing to their potential as alternative biocontrol agents, and several phage-based products (e.g., Agriphage, Biotector, BAFADOR, EcoShield, Listex P-100, SalmoFresh, Salmonelex, and PhageGuards) for improved food safety and management of agricultural pathogens have been commercialized [28]. In aquaculture, several studies have verified the promising potential of phages as alternative biocontrol agents against several bacterial pathogens in fish and shellfish [29-31]. In addition, the protective effects of phages against $A$. salmonicida infections have also been established [32-34].

The overview of phage applications to control several bacterial diseases in aquaculture, including their general advantages, has been properly described in previous reviews [29-31, 35-38]. This review focuses on the recent advances in the study of $A$. salmonicida to improve the understanding of this important bacterial pathogen in the global salmonid industry. It also provides insights into phages that infect Aeromonadaceae, their use in the control of A. salmonicida, and the way forward in aquaculture.

\section{Aeromonas salmonicida}

\section{History of Findings and Classifications}

A. salmonicida has been recognized as one of the most important fish pathogens for over 100 years. The authentic isolation of $A$. salmonicida and the manifestations of its clinical signs, including furuncle-like swelling and ulcerative lesions on infected fish, were first reported by Emmerich and Weibel [14] during a disease outbreak at a Bavarian brown trout hatchery. Since its first isolation, A. salmonicida has been thoroughly investigated and retains its importance as a fish pathogen due to its wide distribution, diverse host range, and devastating economic impact on aquaculture, especially in salmonids [39]. A number of excellent comprehensive reviews on this pathogen, especially on the epizootiological and clinical features including the mechanisms of virulence have been published [39-43].

In the early 20th century, this bacterium was initially referred to as 'Bacterium' or 'Bacillus salmonicida' [44], but was later designated as 'Aeromonas salmonicida' by Griffin et al. [45]. The isolates of the bacterium initially appeared to be homogeneous, but an increasing number of studies later reported several isolates with different biological or biochemical properties from those considered 'typical' from the 1960s [46]. The isolates of Aeromonas salmonicida were classified into two groups, labeled 'typical' and 'atypical' [47], and were divided into three subspecies, subsp. salmonicida, subsp. achromogenes, and subsp. masoucida [48]. The fourth and fifth subspecies, subsp. smithia and subsp. pectinolytica, were later proposed by Austin et al. [49] and Pavan et al. [50], respectively. The List of Prokaryotic Names with Standing in Nomenclature (LPSN; http://www.bacterio.net) [51] now recognizes the five subspecies of A. salmonicida: subsp. salmonicida, achromogenes, masoucida, smithia, and pectinolytica, and currently classifies A. salmonicida subsp. salmonicida as 'typical' and any isolate deviating phenotypically as 'atypical'.

Although the typical isolates form a homogeneous group [13, 52-54], the phenotypical classification of atypical strains has been relatively ambiguous. This is regardless of the attempts to classify them into several subspecies
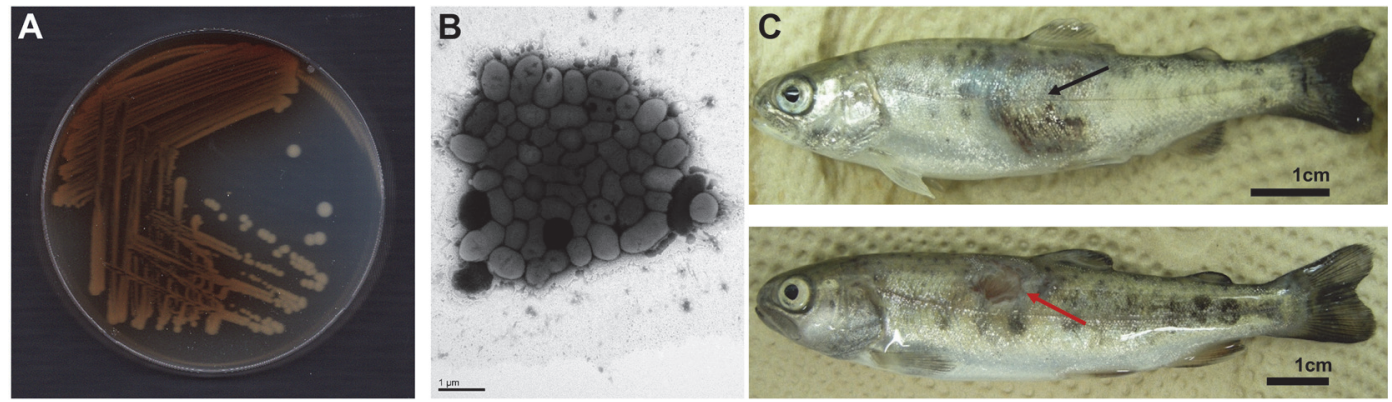

Fig. 1. Characteristics of A. salmonicida subsp. salmonicida (A and B) and its clinical features in salmonid fish (C). (A) Notable brown pigmentation of typical A. salmonicida (A. salmonicida subsp. salmonicida strain AS01 [25]) cultured at $20^{\circ} \mathrm{C}$ in tryptic soy agar. (B) Transmission electron micrograph of A. salmonicida subsp. salmonicida strain AS01 [25] negatively stained with $2 \%$ uranyl acetate (Zeiss TEM EM902 (Zeiss), $80 \mathrm{kV}$ ). (C) Distinct clinical symptoms of furunculosis caused by A. salmonicida subsp. salmonicida strain AS01 [25] in experimentally infected rainbow trout (O. mykiss). Black and red arrows indicate the notable features of furuncle-like swellings and ulcerative lesions in infected fish, respectively. 
using single gene (e.g., 16S rRNA, gyrB, and $r p o D$ ) sequencing and molecular fingerprinting tools (e.g., amplified fragment length polymorphism, restriction fragment length polymorphism, and pulsed field gel electrophoresis) $[42,44]$. In general, typical strains grow well on blood agar with large colonies, produce a brown diffusible pigment, are $\beta$-hemolytic, and do not ferment sucrose [55]. Therefore, morphological and biochemical factors, such as pigment production, colony size and growth rate, hemolysis, and sucrose fermentation, are used to distinguish typical and atypical isolates $[13,42,52,55]$ (Fig. 1). However, recent molecular phylogenetic analyses based on multilocus sequence typing [56] and comparative genomic analyses [57, 58] indicated that the five subspecies form a tight phylogenetic cluster, which confirmed their joint classification as subspecies of A. salmonicida, and this has facilitated the revision of the complex taxonomy and classification of the species in the genus Aeromonas. Moreover, genome-based phylogeny revealed that $A$. salmonicida isolates from different geographical origins are much more diverse than previously thought, and some of these might even be categorized as the sixth new subspecies in the species [57].

\section{Genome of A. salmonicida}

Among the genus Aeromonas, A. salmonicida is one of the most thoroughly genome-sequenced species to date [59]. A total of 68 genome sequences (either complete or draft) are available in the GenBank database (accessed in May 2020), which includes 59 genomes for subsp. salmonicida, five for subsp. achromogenes, and two for subsp. masoucida and pectinolytica each (https://www.ncbi.nlm.nih.gov/genome/browse/\#!/prokaryotes/540/). With the recent technical advances in genome sequencing, the first complete genome sequence of $A$. salmonicida subsp. salmonicida (strain A449) was determined in 2008 [2]. The genomes of A. salmonicida subsp. achromogenes, subsp. masoucida, and subsp. pectinolytica were reported in 2013 [60] and 2018 [58, 61], respectively. The A449 genome contained one chromosome (4,702,402 bp encoding 4,388 genes) and two large plasmids (166,749 bp encoding 178 genes and 155,098 bp encoding 164 genes). Notable features were a large inversion in the chromosome and the presence of a Tn21 composite transposon containing mercury resistance genes and an In 2 integron coding genes for resistance to streptomycin-spectinomycin, quaternary ammonia compounds, sulphonamides, and chloramphenicol. Moreover, genomic analyses of the A449 strain showed that the chromosome bears two prophages (prophage 1 and 2) sharing structural similarities with the temperate phage $\varphi \mathrm{O} 18 \mathrm{P}$ [62], found in A. media. The presence of prophages in A. salmonicida is of interest in its current genome research because most of the genomes of the isolates from different geographical origins possess the two prophages, while another type of prophage (prophage 3 ) was recently discovered only in North American isolates $[63,64]$. Interestingly, those prophage-containing regions are widely distributed in the various available genomes of other Aeromonas spp. in the GenBank database; however, significant similarities between the region and the genomes of other phages are only found in the phages infecting Enterobacteriaceae and Vibrionaceae, rather than Aeromonadaceae [63]. These results suggest that the prophages found in the genome of A. salmonicida may have independently evolved from other known phages that infect the bacteria (Ji Hyung Kim, personal communication). Although its exact function has not yet been verified, the prophages in A. salmonicida will also be implicated in protection against phages as other prophages in both gram-negative and gram-positive bacteria can provide resistance to infection from other phages by superinfection exclusion systems [65].

\section{A. salmonicida subsp. salmonicida and Furunculosis}

From its first discovery in 1894, the disease caused by A. salmonicida was named 'furunculosis' due to its symptom of a furuncle-like swelling, which becomes ulcerative in a later stage of the disease (Fig. 1). However, the discrepancy in the taxonomy of the species has also affected the nomenclature used for the diseases caused by this pathogen. In the pioneer era, the term 'furunculosis' was used principally to cover all fish diseases caused by A. salmonicida species, even though it was later specifically used for those infections of salmonids which showed the furuncle-like swellings [40]. Ljungberg and Johansson [66] suggested that it was essential from an epizootiological point of view to identify typical and atypical A. salmonicida infections as two separate diseases. Subsequently, several diseases caused by atypical isolates in non-salmonid fish have been reported [67], and therefore, only infections caused by A. salmonicida subsp. salmonicida should be referred to as furunculosis [42, 68].

A. salmonicida has extensive host ranges in wild and farmed fish of all ages, and its infections occur in fresh water, brackish, and marine environments [42]. Furthermore, it has been indicated that almost all fish species can serve as reservoirs of infection caused by A. salmonicida [69], and salmonids are considered to be the most susceptible to furunculosis, especially Atlantic salmon (Salmo salar L.), brook trout (Salvelinus fontinalis), and brown trout (Salmo trutta L.). However, rainbow trout (Oncorhynchus mykiss) is considered relatively resistant to this bacterium [40]. Although A. salmonicida is regarded mainly as a primary pathogen only in a variety of fishes and not in humans, as they cannot grow at $37^{\circ} \mathrm{C}$, several recent reports have indicated that it can cause human infections resulting in septicemia and endocarditis [15-17]. Therefore, in this review, the term furunculosis is used for infections caused by subsp. salmonicida and we only focus on the significant features of the subspecies as it concerns the field of aquaculture.

\section{Emergence of Antimicrobial Resistance (AMR)}

The increased frequency of AMR among A. salmonicida was first reported in the USA as early as 1967 [70]. Although the emergence and acquisition of resistance in A. salmonicida against several classes of antibiotics that are commonly used in aquaculture (e.g., $\beta$-lactams, tetracyclines, quinolones, florfenicols, and folate-pathway inhibitors) has been reported, the treatment of the infection is still mostly dependent on the administration of 
antibiotics [43]. Moreover, several typical strains showing multi-drug resistance have been isolated in recent years $[25,69,71,72]$.

Among the antibiotics utilized in the treatment of furunculosis in aquaculture, the mechanisms of resistance to both tetracycline and quinolone have been thoroughly investigated in the subsp. salmonicida [73-75]. Previous studies have indicated that the genetic determinants associated with tetracycline resistance (e.g., tet $A$ to $E$ ) in the species are mostly encoded on the plasmids, and some of the tetracycline-resistant genes are homologous to the ones identified in human and veterinary pathogens $[44,76,77]$. These findings have led to concerns for public health regarding the risk of transfer of AMR to other clinically-relevant pathogens of fish and other animals. In addition, quinolones are the main drug of choice for the treatment of clinical Aeromonas infections [78, 79], and they are also used for the treatment of furunculosis and other bacterial fish diseases [80]. In general, quinolone resistance in the genus Aeromonas has been associated with 1) plasmid-mediated quinolone resistance (PMQR due to qnr variants) [81], 2) mutations in the quinolone resistance-determining regions (QRDRs) of DNA gyrase and topoisomerase IV [78], and 3) active efflux pump [80]. Among those, the presence of mutations on QRDRs and an active efflux pump belonging to the resistance-nodulation-cell division family that could contribute to quinolone resistance have been reported in quinolone-resistant A. salmonicida even recently [25, 78, 80]. Although the significant emergence of PMQR has not been reported in A. salmonicida, this species has strong potential to take up and spread the qnr variants to other human and veterinary pathogens as well as other species in the genus Aeromonas [81].

\section{Disease Control and Alternative Approaches}

Furunculosis was the first bacterial disease in fish to be treated with antibiotics including sulfonamides and nitrofurans [82], and the outbreaks caused by A. salmonicida are usually controlled with chemotherapy [23, 40]. Although other antibiotics effectively control this disease [69], the U.S. Food and Drug Administration imposes stringent restrictions on antibiotics use in the aquaculture industry, and only the use of sulfamerazine, oxytetracycline, and the potentiated sulfonamide Ro5-0037 or ROMET is approved in the USA [83]. In other countries, several antimicrobial agents have been used to control furunculosis, including chloramphenicol, thiophenicol, furazolidone and oxytetracycline, sulphamerazine, tetracycline, a combination of trimethoprim and sulphonamide, flumequine, oxolinic acid, florfenicol, amoxicillin, and enrofloxacin [40, 69, 84, 85]. Despite the emerging concern on the development of AMR in A. salmonicida, the control of pathogens in aquaculture is still mostly reliant on the use of antibiotics.

The global aquaculture industry has adopted vaccination against fish pathogens [86], and several vaccines against typical $A$. salmonicida strains were recently developed to provide long-lasting protection. Their use is promoted in commercial salmonid culture $[23,87,88]$. However, the administration of the vaccines by injection involves substantial regulation in aquaculture (e.g. with regard to the numbers, ages, and sizes of fish to be vaccinated) [89] as the vaccines have been linked to a variety of side effects such as impaired growth, inflammation, fibrous adhesions in the internal organ, scarification, and pigment deposition [90-93].

Due to the emergence of AMR and the limitations of vaccination, interest is growing in the use of alternative approaches to prevent and control $A$. salmonicida infections. The use of probiotics has been relatively properly investigated and several bacterial strains, such as Carnobacterium [94] and lactic acid bacteria [95, 96], are beneficial for the control of bacterial infections. However, the use of probiotics to control furunculosis is still questionable, as the effects have been variable, and it has been difficult to replicate some results [43, 97]. Some other substances, such as natural products, red clay, and immunostimulants, efficiently inhibit bacterial growth in vitro or protect against $A$. salmonicida infection in fish [21,98-101]. Moreover, phages that infect $A$. salmonicida have received much attention as alternative biocontrol agents against the bacteria. In this review, we present the recent advances in understanding the viral diversity of phages that infect $A$. salmonicida and their applications in the global aquaculture industry.

\section{Phages Infecting A. salmonicida and Their Applications in Aquaculture \\ General Description of Phages}

Phages are bacterial viruses that infect bacterial cells, disrupt bacterial metabolism, and cause the bacterium to lyse. They are the most abundant living entities on earth, and they play major roles in bacterial ecology, adaptation, evolution, and pathogenesis [102]. Phages are common in soils (approximately $10^{7}$ to $10^{9}$ virions/g) and highly abundant in fresh water as well as marine ecosystems (approximately $10^{7}$ virions $/ \mathrm{ml}$ ), and their total number on earth was once estimated at $10^{31}$ virions [103].

The discovery of phages was initially reported by Ernest $\mathrm{H}$. Hankin in 1896 when the first evidence for a virallike agent with antibacterial properties against Vibrio cholera was observed [27]. Afterwards, phages were rediscovered twice at the beginning of the 20th century. Frederick W. Twort, an English medical bacteriologist, described a marked antibacterial activity in Micrococcus by an unknown agent in 1915, and 2 years later, phages were "officially" discovered by Felix H. d'Herelle, a French-Canadian microbiologist at the Institut Pasteur [104]. He discovered the destruction of Shigella in broth culture, recognized the viral nature of this phenomenon and suggested the term 'bacteriophage' [105]. The viral nature of phages was recognized in 1940 with the development of the electron microscope, and the basis of the present phage classification was proposed by Bradley in 1967 [106] as six types-tailed phages, filamentous phages, and icosahedral phages with single-stranded (ss) DNA or ssRNA.

At present, the classification and naming of phages is maintained by the Bacterial and Archaeal Subcommittee within the International Committee on Taxonomy of Viruses (ICTV) [107]. Phages have been classified based on the various viral properties such as virion morphology (the structure of the viral capsid and presence of envelops), 
genome type of the virus (ssDNA, dsDNA, ssRNA, or dsRNA), the species of host bacteria, life cycle (lytic or lysogenic), and genome similarity [108]. However, due to the complexity of features that contribute to the taxonomy of phages, their classification is complex and still evolving. In 1971, ICTV classified phages into only six genera (T4, $\lambda, \varphi \mathrm{X} 174, \mathrm{MS} 2$, fd, and PM2) [109]. Later, the classification of phages was revised based on the capsid morphology of the virion, and the classes include polyhedral (Microviridae, Corticoviridae, Tectiviridae, Leviviridae and Cystoviridae), filamentous (Inoviridae), pleomorphic (Plasmaviridae), and tailed (Caudovirales) [110]. Since then, new phage groups have been continuously added, particularly tailed phages containing dsDNA genome. In addition, only a few phage types containing lipid or with a lipid-containing envelop have been found [111]. The 1999 ICTV report classified tailed phages into three families, 16 genera, and 30 species, but its 2018 report revised them into five families, 26 subfamilies, 363 genera, and 1,320 species (https://talk.ictvonline.org/ taxonomy/p/taxonomy_releases). Recent advances in next-generation sequencing (NGS) technologies unveiled the 'hidden' genomic and metagenomic sequence of unknown phages, but unfortunately, a systematic classification of these phage genomes into the ICTV scheme is not available due to lack of related biological properties [112-114]. Therefore, taxonomical revision based on the genomic information of phages has become indispensable, and modernized comprehensive guidelines for phage classification have been recently suggested, which is expected to cause a substantial increase in the list of virus taxa in the coming years $[115,116]$.

As for their bactericidal mechanisms, phages are known to have two possible life cycles; the 'lytic' (or virulent) and 'lysogenic' (or temperate) cycles [117]. Lytic phages rapidly multiply and kill the host cell at the end of the replication cycle. Moreover, temperate phages that undergo the lysogenic cycle persist in a lysogenic state, whereby the phage genome can exist indefinitely when inserted in bacterial chromosome (known as the prophage state). For example, the lysogenic life cycle of $\lambda$ phage ensures the replication of the integrated prophage along with the bacterial genome for many generations. When induction occurs through DNA damage (UV irradiation or exposure to mutagens), which signifies the imminent death of the host, the phage switches to the lytic cycle which results in the release of new phage particles. Interestingly, it has been reported that temperate phages transfer foreign genes into their host bacteria, including toxins and other virulence determinants [118]. In fact, some prophages can change non-pathogenic bacteria to pathogenic ones through lysogenic conversion mechanism, which is now considered the most ostensible contribution to their pathogenesis. In fact, many of the toxins that are responsible for diseases such as diphtheria, cholera, hemolytic-uremic syndrome, botulism, or food poisoning are encoded by temperate phages, and in some cases, their expression also relies on the phages by linking of their regulation to the lytic cycle [119]. Several examples of toxin gene and pathogenic island insertions of temperate phage to host bacterium have been comprehensively reviewed in the literature $[119,120]$. Moreover, the role of phage-mediated transduction and lysogenic conversion in the spread of AMR determinants is a recent topic of research although these genes are much more often found in conjugative genetic elements than in phages. Moreover, several cases on the presence of AMR genes in the phages and prophages have been identified, thus suggesting that phages could play an important role in their transmission between bacterial communities and deserve further attention in the future [121,122].

In addition, bacteria and their associated phages undergo continuous cycles of evolution to generate resistance to each other through an antagonistic, microscopic arms race $[65,123]$. The innate and adaptive bacterial resistance (or immune) systems discovered in response to invading phages are enormously diverse, and much still remains to be discovered [124]. Currently described bacterial innate phage-resistnace mechanisms involve i) aversion of phage adsorption or ii) blockage of phage DNA entry. When these mechanisms fail bacterial protection, iii) the abortive infection triggers the suicide of phage-infected bacterial cells by preventing replication of progeny virus, which finally benefits the bacterial population adjacent to the infected ones [124]. On the other hand, iv) a Clustered, Regularly Interspaced, Short Palindromic Repeat (CRISPR) locus is the only known adaptive immune system in bacteria; a short phage-originated DNA fragment is integrated into the CRISPR loci and finally produces specific immunity against the invading phage [65]. In response to these bacterial phageimmune systems, phages simultaneously evolved their own strategies (such as the anti-CRISPR systems) to avoid, circumvent, or subvert those antiviral mechanisms to successfully complete their lytic cycles [124].

Naturally, phages are found wherever their host bacteria exist [125], and there are several reviews that have focused on the viral communities from soil, water, and host-associated systems [126-128]. The prevalence of phage-mediated lysogenic (rather than lytic) infections in the aquatic environment is still controversial, although more than $90 \%$ of known phages are considered temperate in nature [129]. Other more recent studies have reported lower levels of lysogeny in aquatic microbial populations, ranging from 2\% [130] to 47\% [131]. Moreover, recent NGS approaches in microbial genomics have revealed that temperate phages are prevalent in bacteria in every ecosystem and organism, and about half of those genomes contain temperate phages [132, 133], thus indicating that a large percentage of existing phages are lysogenic. However, temperate phages are not suitable candidates for phage therapy because they may not immediately kill the host bacteria and transfer foreign genes into the host as previously described $[119,120]$. Therefore, we will mainly focus on the lytic phages that infect aquatic pathogens including A. salmonicida and their potential applications in aquaculture systems in the subsequent sections of this review.

\section{Therapeutic Application of Phages}

Even though phages were discovered in the early 20th century, research on their possible therapeutic applications against infectious bacterial diseases in the past half century has been limited [134]. This poor understanding of bacterial pathogenesis and phage-host interactions has led to a succession of badly designed and executed experiments. Furthermore, with the advent of antibiotic therapy, the use of phages became 
underexplored, especially after World War II. The discovery of antibiotics diverted research attention from phage therapy, mainly in the USA and Western Europe in the 1940s. However, the use of phage therapy has persisted without interruption in Eastern Europe and the Soviet Union, and a number of companies have even commercialized phages [135]. In the past, with regards to human health, phage was commercialized and administered in Eastern Europe and the Soviet Union orally, topically, or systemically to treat a wide variety of human infections (suppurative wound, gastroenteritis, sepsis, osteomyelitis, dermatitis, emphysema, and pneumonia) in both adults and children with promising results. In the 1970s, the previous enthusiasm on the application of phages to prevent and treat bacterial infections in human was reinvigorated [136, 137]. In 1992, the studies of Soothill, using mice and farm animals infected with E. coli, showed that phages could be used for both the treatment and prevention of bacterial infections [138]. Since then, several other Polish and Soviet Union study groups have presented successful clinical applications of phages against drug-resistant bacterial infections in humans and animal models [136]. The therapeutic efficacy of phages against infectious diseases caused by Pseudomonas aeruginosa, Staphylococcus aureus (including MRSA), E. coli, Enterococcus faecium (including VRE), Streptococcus pneumoniae, Helicobacter pylori, Klebsiella pneumoniae, and Salmonella enteritidis have been demonstrated in various experimental animal models [134, 137, 139-146]. Moreover, in recent decades, the emergence of antibiotic-resistant bacteria has substantially enhanced the interest of researchers in phage therapy, even in the USA and Western Europe. Nowadays, more than a dozen of companies and universities are working on phage therapy for humans, using current standards of clinical and microbiological research $[28,147,148]$.

Numerous recent studies have evaluated phages as biocontrol agents in food [146, 149-151] and plants [152], and for wastewater treatment [153]. Bacterial diseases are a major problem in aquaculture $[134,154,155]$. The increasing problems related to worldwide emergence of AMR in common pathogenic bacteria and the concerns about its spread in aquaculture environments demand alternative control methods for bacterial pathogens in fish and shellfish. In aquaculture, phage therapy is a potentially viable alternative to antibiotics in the control of indigenous and non-indigenous bacterial disease in farmed fish and shellfish [29-31]. In addition, some studies on phages have involved the identification of phages for use in bacterial typing schemes or for characterization, including investigation of their potential role in virulence [155-157]. Remarkably, several studies have demonstrated the ability of phages to prevent or control bacterial infections associated with Vibrio spp., Flavobacterium spp., Aeromonas spp., Pseudomonas spp., and Lactococcus spp. in aquaculture in fish or shellfish [29-31]. In the same manner, there have been several reports of the antibacterial effects of phages against A. salmonicida infections in aquaculture [32-34].

\section{Phages Infecting Aeromonadaceae (Especially A. salmonicida)}

Historically, phages that infect Aeromonadaceae (hereinafter referred to as Aeromonas phages) have been studied for a relatively long time compared to other bacterial species, and a large number of phages have been isolated and characterized. The first Aeromonas phage with morphological features based on the electron microscope was reported in 1965 [158]. Its host, which was identified as an Acetobacter sp., was later reclassified as Aeromonas sp. [159]. Subsequently, Paterson isolated nine Aeromonas phages infecting A. salmonicida from trout ponds and fish hatcheries and described the characteristics of some selected phage isolates [160]. A halophilic and psychrophilic phage, specific for a marine Aeromonas spp., was isolated from seawater collected at a depth of $825 \mathrm{~m}$ [161]. In 1971, 35 Aeromonas phages infecting A. salmonicida, isolated from sewage, surface water, fish hatcheries, and lysogenic bacteria, were characterized by serology and various biological criteria. Sixteen of these phages were studied by electron microscopy and were divided into three morphological groups [162]. During the last decades, a number of lytic and/or lysogenic phages infecting A. salmonicida have been described and characterized [159, 163-167]. However, their classification depended largely on morphology and serological data due to the absence of the physicochemical and genetic properties of the isolated phages [159]. In fact, many Aeromonas phages were described without accurate morphological micrographs, until the first morphological characteristics of about 35 Aeromonas phages, mostly those that infect A. salmonicida, were thoroughly investigated by Ackermann [159]. In the more recent review by Ackermann [102], a total of 43 previously isolated Aeromonas phages (mainly infecting A. hydrophila and A. salmonicida) were reinvestigated, and all them were morphologically classified as tailed members of Caudovirales (Myoviridae $(n=33)$, Siphoviridae $(n=7)$, and Podoviridae ( $n=3$ ) (recently classified as Autographiviridae) [114]). Furthermore, most of the phages that belong to the family Myoviridae were classified into P1-, P2-, and T4-like viruses in the VIII ${ }^{\text {th }}$ ICTV Report (http:// www.ictvdb.org/Ictv/index.htm) [168].

The recent advances in genome sequencing technology and its adaptations in the phage taxonomy facilitates the investigation of the morphology and genetic functions of Myoviridae phages infecting E. coli and other gramnegative bacteria (especially T4 and T4-like viruses), and this provides an attractive model for the study of comparative genomics and evolution of phages $[169,170]$. According to the recent viral taxonomy of the IX ${ }^{\text {th }}$ ICTV Report released in 2019 (https://talk.ictvonline.org/ictv-reports/ictv_9th_report/dsdna-viruses-2011/w/ dsdna_viruses/68/myoviridae), the family Myoviridae has been divided into five subfamilies. Moreover, detailed classification of previously isolated phages using a range of complementary sequence analysis tools as well as phylogenetic methods is still in progress [171]. In this respect, recent studies on Aeromonas phages have also focused on Myoviridae phages and have included extensive genomic investigations to elucidate their plasticity [34, $169,170,172-185]$. A total of 29 complete genomes of phages that infect $A$. salmonicida are currently available in the GenBank database (accessed in May, 2020) (Table 1), and most of the sequenced Aeromonas phages were classified as Myoviridae ( $n=26)$ with the exception of two species in the Autographiviridae family and one species in the Siphoviridae family. Based on this information, it can be assumed that Aeromonas phages belonging to the 
Table 1. List of genomes of phages infecting A. salmonicida available in the GenBank database.

\begin{tabular}{|c|c|c|c|c|c|c|}
\hline Name of phage & Family & Host & $\begin{array}{l}\text { Isolation source } \\
\text { /country }\end{array}$ & $\begin{array}{l}\text { Genome } \\
\text { size (bp) }\end{array}$ & GenBank No. & Reference \\
\hline 51 & $\begin{array}{l}\text { Myoviridae } \\
\text { (Popoffvirus) }\end{array}$ & A. salmonicida & Water/France & 43,551 & KY290953.1 & {$[65]$} \\
\hline 56 & $\begin{array}{l}\text { Myoviridae } \\
\text { (Popoffvirus) }\end{array}$ & A. salmonicida & Water/France & 43,551 & KY290954.1 & {$[65]$} \\
\hline 59.1 & Myoviridae & A. salmonicida & Water/Canada & 46,057 & KY290950.1 & {$[65]$} \\
\hline 3 & Myoviridae & A. salmonicida & Water/France & 46,349 & KY290947.1 & {$[65]$} \\
\hline Asp37 & Myoviridae & A. salmonicida & Water/Canada & 47,977 & KY290949.1 & {$[65]$} \\
\hline 32 & Myoviridae & A. salmonicida & Water/France & 48,252 & KY290952.1 & {$[65]$} \\
\hline 31.2 & $\begin{array}{l}\text { Myoviridae } \\
\text { (Biquartavirus) }\end{array}$ & A. salmonicida & Water/France & 172,957 & KY290951.1 & {$[65]$} \\
\hline SW69-9 & $\begin{array}{l}\text { Myoviridae } \\
\text { (Biquartavirus) }\end{array}$ & A. salmonicida & Water/Canada & 173,097 & KY290958.1 & {$[65]$} \\
\hline L9-6 & $\begin{array}{l}\text { Myoviridae } \\
\text { (Biquartavirus) }\end{array}$ & A. salmonicida & Water/Canada & 173,578 & KY290956.1 & {$[65]$} \\
\hline 44RR2.8t.2 & $\begin{array}{l}\text { Myoviridae } \\
\text { (Biquartavirus) }\end{array}$ & A. salmonicida & Water/Canada & 173,590 & KY290948.1 & {$[65]$} \\
\hline 65.2 & $\begin{array}{l}\text { Myoviridae } \\
\text { (Tevenvirinae) }\end{array}$ & A. salmonicida & Water/France & 236,567 & KY290955.1 & {$[65]$} \\
\hline Aes508 & $\begin{array}{l}\text { Myoviridae } \\
\text { (Tulanevirus) }\end{array}$ & A. salmonicida & N/A/USA & 160,646 & NC_019543.1 & {$[65]$} \\
\hline AS-szw & $\begin{array}{l}\text { Myoviridae } \\
\text { (Tevenvirinae) }\end{array}$ & $\begin{array}{l}\text { A. salmonicida } \\
\text { subsp. salmonicida }\end{array}$ & Water/China & 29,957 & MF498773.1 & {$[183]$} \\
\hline AS-gz & $\begin{array}{l}\text { Myoviridae } \\
\text { (Tulanevirus) }\end{array}$ & $\begin{array}{l}\text { A. salmonicida } \\
\text { subsp. salmonicida }\end{array}$ & Water/China & 162,422 & NC_042019.1 & [183] \\
\hline AS-zj & $\begin{array}{l}\text { Myoviridae } \\
\text { (Tulanevirus) }\end{array}$ & $\begin{array}{l}\text { A. salmonicida } \\
\text { subsp. salmonicida }\end{array}$ & Water/China & 229,929 & MF448340.1 & [183] \\
\hline AS-sw & $\begin{array}{l}\text { Myoviridae } \\
\text { (Tulanevirus) }\end{array}$ & $\begin{array}{l}\text { A. salmonicida } \\
\text { subsp. salmonicida }\end{array}$ & Water/China & 230,024 & MF498775.1 & {$[183]$} \\
\hline AS-yj & $\begin{array}{l}\text { Myoviridae } \\
\text { (Tulanevirus) }\end{array}$ & $\begin{array}{l}\text { A. salmonicida } \\
\text { subsp. salmonicida }\end{array}$ & Water/China & 230,183 & MF498774.1 & {$[183]$} \\
\hline 25 & $\begin{array}{l}\text { Myoviridae } \\
\text { (Tulanevirus) }\end{array}$ & A. salmonicida & Fish farm/France & 161,475 & NC_008208.1 & {$[170]$} \\
\hline 31 & $\begin{array}{l}\text { Myoviridae } \\
\text { (Biquartavirus) }\end{array}$ & A. salmonicida & Fish farm/France & 172,963 & NC_007022.1 & {$[170]$} \\
\hline 65 & $\begin{array}{l}\text { Myoviridae } \\
\text { (Tevenvirinae) }\end{array}$ & A. salmonicida & River/France & 235,229 & NC_015251.1 & {$[170]$} \\
\hline PX29 & $\begin{array}{l}\text { Myoviridae } \\
\text { (Tevenvirinae) }\end{array}$ & A. salmonicida & Sewage/USA & 222,006 & NC_023688.1 & [202] \\
\hline vB_AsaM-56 & $\begin{array}{l}\text { Myoviridae } \\
\text { (Popoffvirus) }\end{array}$ & A. salmonicida & Freshwater, France & 433,551 & NC_019527.1 & {$[177]$} \\
\hline $44 \mathrm{RR} 2.8 \mathrm{t}$ & $\begin{array}{l}\text { Myoviridae } \\
\text { (Biquartavirus) }\end{array}$ & A. salmonicida & Fish farm/Canada & 173,591 & NC_005135.1 & {$[173]$} \\
\hline AsXd-1 & Siphoviridae & A. salmonicida & Wastewater/China & 39,014 & MH178096.1 & [184] \\
\hline phiAS4 & $\begin{array}{l}\text { Myoviridae } \\
\text { (Tulanevirus) }\end{array}$ & A. salmonicida & River/Korea & 163,875 & HM452125.1 & {$[178]$} \\
\hline phiAS5 & $\begin{array}{l}\text { Myoviridae } \\
\text { (Tevenvirinae) }\end{array}$ & A. salmonicida & River/Korea & 225,268 & NC_014636.1 & [179] \\
\hline phiAS7 & Autographiviridae & $\begin{array}{l}\text { A. salmonicida } \\
\text { subsp. salmonicida }\end{array}$ & Fish farm/Korea & 41,572 & NC_019528.1 & {$[180]$} \\
\hline Asfd_1 & $\begin{array}{l}\text { Myoviridae } \\
\text { (Biquartavirus) }\end{array}$ & A. salmonicida & Sewage/China & 168,962 & MK577502.1 & {$[186]$} \\
\hline PS & Autographiviridae & A. salmonicida & Sewage/India & 41,082 & MT259468.1 & N/A \\
\hline AS-A & Myoviridae & A. salmonicida & Sewage/Portugal & N/A & N/A & {$[34,185]$} \\
\hline PAS-1 & Myoviridae & $\begin{array}{l}\text { A. salmonicida } \\
\text { subsp. salmonicida }\end{array}$ & Fish farm/Korea & N/A & $\begin{array}{l}\text { JF342683.1- } \\
\text { JF342690.1 }\end{array}$ & [181] \\
\hline
\end{tabular}

${ }^{*} \mathrm{~N} / \mathrm{A}$, not available.

*The genome data of phages in the GenBank database were accessed in May 2020.

Myoviridae family are more prevalent than the other phages. In addition, further research on Aeromonas phages to unveil their diversity in aquatic environments and explore their biotechnological applications in aquaculture is expected. The recent advances in metagenomics have enabled us to understand the diversity of the viral community and obtain various in silico genomes of phages from aquatic environments $[186,187]$. Thus, the discovery of several novel Aeromonas phage genomes is expected in the future.

Although much effort has been made to understand phage adsorption and identify receptors involved in the 
lytic cycle of phages in various bacterial species [188], studies on finding bacterial receptors and understanding the resistance mechanism in A. salmonicida against its phages are still elusive and much still remains to be discovered [189]. Among the large numbers of isolated phages infecting A. salmonicida, only three studies have characterized the bacterial receptor of the specific phages; lipid A of the lipopolysaccharide was identified as a receptor for the phage 55R-1, and A-layer (or S-layer), was also reported as a receptor for phages TP446 and SW699 , respectively [189]. Based on these results, it can be suggested that modifications to the receptors in the outer membrane protein might be among the most important mechanisms of resistance to phages for A. salmonicida. Furthermore, the phage receptors in this species could be more diverse than previously thought. However, much work still needs to be done in future.

\section{Application of Phages Infecting A. salmonicida and Future Perspectives}

A number of phages infecting various bacterial pathogens of fish and shellfish have been isolated and the therapeutic (or prophylactic) application of those phages in aquatic animal models has demonstrated their promising potential as alternative antimicrobial agents in aquaculture [29, 30]. Although Aeromonas spp. are recognized as the third most targeted aquatic bacterial pathogens in phage application research [31], historically, the genus was the first reported target of phage application in aquaculture [190]. Since then, numerous studies, mainly focused on A. hydrophila and A. salmonicida, have evaluated the therapeutic (or prophylactic) potential of Aeromonas phages in various fish species, and the phages have produced promising results as alternative biocontrol agents in aquaculture.

A. salmonicida is principally recognized in cultured salmonid species as a major pathogenic bacteria causing significant economic losses in the global salmonid farming industry [191]. Therefore, numerous studies have been conducted to evaluate antimicrobial activity using various A. salmonicida strains and their phages (including phage cocktails) and have shown sufficient biocontrol efficacy of phages at the in vitro and/or in vivo levels [32-34, 180, 182, 192-194] (Table 2). Among them, therapeutic (or prophylactic) applications of phages against A. salmonicida have been conducted to control furnunculosis in farmed brook trout (S. fontinalis) [32], Atlantic

Table 2. List of phage-biocontrol approaches against $A$. salmonicida in aquaculture.

\begin{tabular}{|c|c|c|c|c|c|c|c|}
\hline $\begin{array}{l}\text { Bacterial } \\
\text { strain }\end{array}$ & Fish species & Challenge & Phages & $\begin{array}{l}\text { Administration } \\
\text { (efficient } \mathrm{MOI}^{\star} \text { ) }\end{array}$ & $\begin{array}{c}\text { Biocontrol } \\
\text { potential }\end{array}$ & Results & Reference \\
\hline HER1107 & $\begin{array}{l}\text { Brook trout } \\
\text { (S. fontinalis) }\end{array}$ & Immersion & HER 110 & $\begin{array}{l}\text { Immersion } \\
\text { (1) }\end{array}$ & Yes & $\begin{array}{l}\text { Delayed onset of } \\
\text { furunculosis by } 7 \mathrm{~d} \text { and } \\
\text { reduced total mortality } \\
\text { rates from } 100 \% \text { to } 10 \%\end{array}$ & {$[32]$} \\
\hline $\begin{array}{l}\text { Cefas } \\
78027\end{array}$ & $\begin{array}{l}\text { Atlantic salmon } \\
\text { (S. salar) }\end{array}$ & $\begin{array}{l}\text { Cohabitation or } \\
\text { I.P. injection }\end{array}$ & $\begin{array}{l}\mathrm{O}, \mathrm{R}, \\
\text { and } \mathrm{B}\end{array}$ & $\begin{array}{l}\text { Various } \\
\text { methods } \\
\text { (Various } \\
\text { MOIs }^{* *} \text { ) }\end{array}$ & No & $\begin{array}{l}\text { No protective effects were } \\
\text { observed }\end{array}$ & [193] \\
\hline $\begin{array}{l}\text { AS01, } \\
\text { ATCC } \\
27013\end{array}$ & $\begin{array}{l}\text { ND } \\
\text { (in vitro only) }\end{array}$ & $\begin{array}{l}\text { ND } \\
\text { (in vitro only) }\end{array}$ & PAS-1 & $\begin{array}{l}\text { ND } \\
(0.1)\end{array}$ & Yes & $\begin{array}{l}\text { Bacterial growths were } \\
\text { apparently retarded until } \\
24 \mathrm{~h}\end{array}$ & [181] \\
\hline AS05 & $\begin{array}{l}\text { Rainbow trout } \\
(\text { O. mykiss })\end{array}$ & I.M. injection & PAS-1 & $\begin{array}{l}\text { I.M. injection } \\
(10,000)\end{array}$ & Yes & $\begin{array}{l}\text { Notable protective effects } \\
\text { with increased survival } \\
\text { rates }(0 \% \text { to } 30 \%) \text {. } \\
\text { Neutralizing activity } \\
\text { against PAS- } 1 \text { was detected } \\
\text { in the phage-treated fish }\end{array}$ & {$[33]$} \\
\hline $\begin{array}{l}\text { CECT } \\
894\end{array}$ & $\begin{array}{l}\text { Senegalese sole } \\
(\text { S. senegalensis })\end{array}$ & Immersion & AS-A & $\begin{array}{l}\text { Immersion } \\
(100)\end{array}$ & Yes & $\begin{array}{l}\text { Inhibition of bacterial } \\
\text { growth both in the } \\
\text { seawater and batch cultures } \\
\text { with fish, and no mortality } \\
\text { was observed compared to } \\
\text { control group ( } 36 \%) \text {. }\end{array}$ & {$[34]$} \\
\hline AS-sz & $\begin{array}{l}\text { ND } \\
\text { (in vitro only) }\end{array}$ & $\begin{array}{l}\text { ND } \\
\text { (in vitro only) }\end{array}$ & $\begin{array}{l}\text { AS-szw, } \\
\text { AS-yj, } \\
\text { AS-zj, } \\
\text { AS-sw, } \\
\text { and } \\
\text { AS-gz }\end{array}$ & $\begin{array}{l}\text { ND } \\
(0.01)\end{array}$ & Yes & $\begin{array}{l}\text { Efficient phage cocktail } \\
\text { was designed and its } \\
\text { synergetic antimicrobial } \\
\text { activity was confirmed }\end{array}$ & [183] \\
\hline $\begin{array}{l}\text { CECT } \\
894\end{array}$ & $\begin{array}{l}\text { ND } \\
\text { (in vitro only) }\end{array}$ & $\begin{array}{l}\text { ND } \\
\text { (in vitro only) }\end{array}$ & $\begin{array}{l}\text { AS-A, } \\
\text { AS-D, } \\
\text { and } \\
\text { AS-E }\end{array}$ & $\begin{array}{l}\text { ND } \\
(100)\end{array}$ & Yes & $\begin{array}{l}\text { Efficient phage cocktail } \\
\text { was designed and its } \\
\text { synergetic antimicrobial } \\
\text { activity was confirmed }\end{array}$ & [194] \\
\hline $\begin{array}{l}\text { Unnamed } \\
\text { isolate }\end{array}$ & $\begin{array}{l}\text { ND } \\
\text { (in vitro only) }\end{array}$ & $\begin{array}{l}\text { ND } \\
\text { (in vitro only) }\end{array}$ & ASP-1 & $\begin{array}{l}\text { ND } \\
(0.01)\end{array}$ & Yes & $\begin{array}{l}\text { Bacterial growths were } \\
\text { apparently retarded until } \\
12 \mathrm{~h}\end{array}$ & [195] \\
\hline
\end{tabular}

${ }^{\star}$ MOI, Multiplicity of infection.

${ }^{*}$ The exact administration methods of phages and MOIs can be found in Verner-Jeffreys et al. [193]. 
salmon (S. salar) [192], and rainbow trout (O. mykiss) [33]. Although Verner-Jeffreys et al. did not find any protective effects against A. salmonicida in phage-treated fish [192], the other two studies showed clear differences between the phage-treated group and the control group. Imbeault et al. reported that the administration of phage HER110 delayed onset of furunculosis by $7 \mathrm{~d}$ with reduced mortality rates of the fish from $100 \%$ to $10 \%$ [32]. Moreover, administration of phage PAS-1 in rainbow trout model showed notable protective effects against A. salmonicida infection with increased survival rates ( $0 \%$ to $30 \%$ ) [33]. In addition, the protective effect of phage against A. salmonicida was also verified in Senegalese sole (Solea senegalensis), showing significantly reduced mortality (36\% to 0\%) [34]. Due to the differences in Aeromonas phages and fish species, it is difficult to generalize the findings of different studies on the effects of phages on bacterial infections in fish. However, previous studies have generally demonstrated the protective effects of phages against $A$. salmonicida infections and their potential efficacy to control furunculosis in aquaculture.

Salmonid farming is currently a major global industry and its growth has been largely supported by the intensification of fish culture. However, the increased level of mortality associated with A. salmonicida and the prevalence of AMR have placed ever-growing importance on the development of alternative control methods against the bacteria [195]. Among the suggested alternatives, the use of phages to control A. salmonicida has shown the most beneficial characteristics, but there are still several limitations to be addressed. The general advantages and limitations of phage applications in aquaculture have been extensively described in previous reviews [29-31, 35-38]. Nevertheless, based on our experience, we highlighted below the challenges associated with the industrial use of Aeromonas phages for the control of A. salmonicida in salmonid farming and how such challenges can be overcome.

1. In terms of phages:

A. Finding Aeromonas phages with broad infectivity is the first step. In our experience, some isolated Aeromonas phages were able to infect several different species of Aeromonas strains as well as other subspecies of $A$. salmonicida $[178,180]$.

B. In aquaculture, the importance of phage genome sequencing tends to be overlooked. The safety of isolated phages should be examined at the genome level, and phages with genes related to lysogenic conversion (such as integrase) or potentially damaging genetic determinants (toxins or AMR genes) should be excluded from further application [196].

C. The emergence of phage-resistant bacteria is one of the major limitations of phage application, and alternatively, a combination of different phages (phage cocktail) or a combination of a phage with antibiotics, preservative, or disinfectants is recommended [35].

2. In terms of A. salmonicida:

A. Regular surveillance studies of $A$. salmonicida isolates from cultured fish will be necessary. For field application, the infectivity of Aeromonas phages against bacteria isolated close to the onset of disease should be verified.

B. In aquaculture, the importance of understanding the interactions between host microbe and phage also tends to be overlooked. Understanding the bacterial phage-resistance mechanisms and identifying receptors on the selected phage will be crucial for its successful application in aquaculture [189].

3. In terms of salmonid fish:

A. Although an anti-phage immune response limiting the efficacy of phage therapy has been identified in humans [197], only limited studies on the impact of this immunomodulation during phage administration have been conducted in fish [33,198]. More studies are required to evaluate this anti-phage response in salmonid fish.

B. For the application of phages in aquaculture, selection of methods as well as timing and dosage (multiplicity of infection) of phage administration are considered very important factors [31]. However, prophylactic use of phages, followed by eventual therapeutic use, seems to be the best application strategy for Aeromonas phages in salmonid culture.

Numerous recent applications of phages have shown promising protective efficacy with several advantages over antibiotics. However, more studies geared towards the optimization of phage application under field (or farm scale) conditions rather than lab-scale conditions are required [199]. Moreover, understanding the natural mechanisms that contribute to the emergence of phage-resistant strains and identifying the potential bacterial receptors of specific phages will be crucial to provide a successful path to phage biocontrol as an alternative treatment method in aquaculture [189]. Similar to antimicrobials, the initial idea of phage therapy was for the treatment of diseases; however, considering the nature of the aquaculture industry, future phage research that guarantees industrialization should rather focus on its prophylactic use to reduce potential pathogen loads that can cause severe outbreaks. In addition, there is still a need to overcome the understandable stigma among producers and consumers regarding the safety of phages despite the certification by the regulatory bodies [200]. Notwithstanding the recent increase in scientific interest in the industrial application of phage, only a small number of private companies have publicized their intention to work on phage-based solutions for aquaculture and few products have been commercially released [31]. Therefore, additional efforts are required to assess the understanding of producer and consumer followed by educational campaigns to raise the awareness and acceptance on the use of phages in aquaculture. Although several limitations are still associated with the use of phages, they still have undeniable advantages over the other alternatives. Therefore, exploring phage-based 
products is now more necessary than ever as the aquaculture industry is presently facing increasing problems with AMR pathogens including A. salmonicida.

\section{Concluding Remarks}

Salmonid farming today is a major global industry; however, it is increasingly threatened by economic losses associated with $A$. salmonicida. From the first findings in the $19^{\text {th }}$ century, A. salmonicida has been considered a major bacterial pathogen in aquaculture, especially in salmonid culture. Due to its taxonomical complexity and severe pathogenicity in cultured fish, researchers have been extensively investigating A. salmonicida for several decades. The emergence and spread of AMR in A. salmonicida is of great concern in aquaculture, and interest in the use of alternative approaches to prevent and control infection has increased in recent years.

Several studies have verified the promising potential of phages as biocontrol agents against various bacterial pathogens including fish and shellfish, and the genus Aeromonas, which was the first reported target for the application of phages in aquaculture, has become the third most targeted pathogen in phage application research. Historically, Aeromonas phages have been studied for more than 50 years, and a large number of phages have been isolated and investigated, mainly on their morphological and biological diversity. Moreover, recent studies on Aeromonas phages have focused on extensive genomic investigations to elucidate their plasticity, and further studies are expected to unveil the diversity of Aeromonas phages in aquatic environments. In aquaculture, the biocontrol potential of Aeromonas phages against A. salmonicida has been verified in cultured salmonid species and shows highly promising characteristics; however, more studies are required to optimize phage application under field (or farm-scale) conditions and to understand the interactions between host fish, bacteria and phage. The initial idea of phage therapy was for the treatment of diseases; however, considering the nature of the aquaculture industry, future phage research should focus on prophylactic application to reduce the potential load of pathogens, including A. salmonicida, to prevent severe outbreaks.

\section{Acknowledgments}

This work was supported by the KRIBB Research Initiative Programs, the Collaborative Genome Program of the Korea Institute of Marine Science and Technology Promotion [20180430] funded by the Ministry of Oceans and Fisheries, and Basic Science Research Program (2020R1I1A2A01041221) through the National Research Foundation, funded by the Ministry of Education of Korea.

\section{Conflict of Interests}

The authors have no financial conflicts of interest to declare.

\section{References}

1. Colwell RR, MacDonell MT, De Ley J. 1986. Proposal to recognize the family Aeromonadaceae. Int. J. Syst. Evol. Microbiol. 36: 473477.

2. Reith ME, Singh RK, Curtis B, Boyd JM, Bouevitch A, Kimball J, et al. 2008. The genome of Aeromonas salmonicida subsp. salmonicida A449: insights into the evolution of a fish pathogen. BMC Genomics 9: 427.

3. Janda JM, Abbott SL. 2010. The genus Aeromonas: taxonomy, pathogenicity, and infection. Clin. Microbiol. Rev. 23: 35-73.

4. Fernández-Bravo A, Figueras MJ. 2020. An update on the genus Aeromonas: taxonomy, epidemiology, and pathogenicity. Microorganisms 8: 129 .

5. Igbinosa IH, Igumbor EU, Aghdasi F, Tom M, Okoh AI. 2012. Emerging Aeromonas species infections and their significance in public health. Sci. World J. 2012: 625023.

6. Piotrowska M, Przygodzińska D, Matyjewicz K, Popowska M. 2017. Occurrence and variety of $\beta$-lactamase genes among Aeromonas spp. isolated from urban wastewater treatment plant. Front. Microbiol. 8: 863.

7. Khajanchi BK, Fadl AA, Borchardt MA, Berg RL, Horneman AJ, Stemper ME, et al. 2010. Distribution of virulence factors and molecular fingerprinting of Aeromonas species isolates from water and clinical samples: suggestive evidence of water-to-human transmission. Appl. Environ. Microbiol. 76: 2313-2325.

8. Janda JM. 1991. Recent advances in the study of the taxonomy, pathogenicity, and infectious syndromes associated with the genus Aeromonas. Clin. Microbiol. Rev. 4: 397-410.

9. Chen PL, Lamy B, Ko WC. 2016. Aeromonas dhakensis, an increasingly recognized human pathogen. Front. Microbiol. 7: 793.

10. Parker JL, Shaw JG. 2011. Aeromonas spp. clinical microbiology and disease. J. Infect. 62: 109-118.

11. Aravena-Román M, Inglis TJ, Henderson B, Riley TV, Chang BJ. 2014. Distribution of 13 virulence genes among clinical and environmental Aeromonas spp. in Western Australia. Eur. J. Clin. Microbiol. Infect. Dis. 33: 1889-1895.

12. Figueira V, Vaz-Moreira I, Silva M, Manaia CM. 2011. Diversity and antibiotic resistance of Aeromonas spp. in drinking and wastewater treatment plants. Water Res. 45: 5599-5611.

13. Dalsgaard I, Gudmundsdóttir BK, Helgason S, Høie S, Thoresen OF, Wichardt UP, et al. 1998. Identification of atypical Aeromonas salmonicida: inter-laboratory evaluation and harmonization of methods. J. Appl. Microbiol. 84: 999-1006.

14. Emmerich R, Weibel E. 1894. Ueber eine durch Bakterien erengte Seuche unter den Forellen. Archives fur Hygiene und Bakteriologie 21: $1-21$.

15. Tewari R, Dudeja M, Nandy S, Das, AK 2014. Isolation of Aeromonas salmonicida from human blood sample: a case report. J. Clin. Diagn. Res. 8: 139.

16. Salehi MR, Shadvar S, Sadeghian, M, Doomanlou M, Abdollahi A, Manshadi SA D, et al. 2019. Endocarditis with Aeromonas salmonicida. IDCases 18: e00625.

17. Vincent AT, Fernández-Bravo A, Sanchis M, Mayayo, E, Figueras, MJ, Charette SJ. 2019. Investigation of the virulence and genomics of Aeromonas salmonicida strains isolated from human patients. Infect. Genet. Evol. 68: 1-9.

18. Inglis V, Robertson D, Miller K, Thompson KD, Richards RH. 1996. Antibiotic protection against recrudescence of latent Aeromonas salmonicida during furunculosis vaccination. J. Fish Dis. 19: 341-348.

19. Sommerset I., Krossøy B, Biering E, Frost P. 2005. Vaccines for fish in aquaculture. Exp. Rev. Vaccines 4: 89-101. 
20. Gudding R,Van Muiswinkel WB. 2013. A history of fish vaccination: science-based disease prevention in aquaculture. Fish Shellfish Immun. 35: 1683-1688

21. Menanteau-Ledouble S, Krauss I, Santos G, Fibi S, Weber B, El-Matbouli M. 2015. Effect of a phytogenic feed additive on the susceptibility of Onchorhynchus mykiss to Aeromonas salmonicida. Dis. Aquat. Organ. 115: 57-66.

22. Barnes AC, Horne MT, Ellis AE. 1996. Effect of iron on expression of superoxide dismutase by Aeromonas salmonicida and associated resistance to superoxide anion. FEMS Microbiol. Lett. $142: 19-26$.

23. Cipriano RC, Bullock GL. 2001. Furunculosis and other diseases caused by Aeromonas salmonicida. US Fish and Wildlife Service, USGS, Kearneysville. Fish Disease Leaflet 66.

24. Dacanay A, Johnson SC, Bjornsdottir R, Ebanks RO, Ross NW, Reith M, et al. 2003. Molecular characterization and quantitative analysis of superoxide dismutases in virulent and avirulent strains of Aeromonas salmonicida subsp. salmonicida. J. Bacteriol. 185: 4336-4344.

25. Kim JH, Hwang SY, Son JS, Han JE, Jun JW, Shin SP, et al. 2011. Molecular characterization of tetracycline-and quinolone-resistant Aeromonas salmonicida isolated in Korea. J. Vet. Sci. 12: 41-48.

26. Hayatgheib N, Moreau E, Calvez S, Lepelletier D, Pouliquen, H. 2020. A review of functional feeds and the control of Aeromonas infections in freshwater fish. Aquacult. Int. 28: 1083-1123.

27. Adhya S, Merril C. 2006. The road to phage therapy. Nature 443: 754-755.

28. Moye ZD, Woolston J, Sulakvelidze A. 2018. Bacteriophage applications for food production and processing. Viruses 10: 205.

29. Nakai T, Park SC. 2002. Bacteriophage therapy of infectious diseases in aquaculture. Res. Microbiol. 153: 13-18.

30. Gon Choudhury T, Tharabenahalli Nagaraju V, Gita S, Paria A, Parhi J. 2017. Advances in bacteriophage research for bacterial disease control in aquaculture. Rev. Fish. Sci. Aquac. 25: 113-125.

31. Culot A, Grosset N, Gautier M. 2019. Overcoming the challenges of phage therapy for industrial aquaculture: a review. Aquaculture 513: 734423.

32. Imbeault S, Parent S, Lagacé M, Uhland CF, Blais JF. 2006. Using bacteriophages to prevent furunculosis caused by Aeromonas salmonicida in farmed brook trout. J. Aquat. Anim. Health 18: 203-214.

33. Kim JH, Choresca CH, Shin SP, Han JE, Jun JW, Park SC. 2015. Biological control of Aeromonas salmonicida subsp. salmonicida infection in rainbow trout (Oncorhynchus mykiss) using Aeromonas phage PAS-1. Transbound Emerg. Dis. 62: 81-86.

34. Silva YJ, Moreirinha C, Pereira C, Costa L, Rocha R J, Cunha Â, et al. 2016. Biological control of Aeromonas salmonicida infection in juvenile Senegalese sole (Solea senegalensis) with phage AS-A. Aquaculture 450: 225-233.

35. Nakai, T. 2010. Application of bacteriophages for control of infectious diseases in aquaculture. In Bacteriophages in the control of food-and waterborne pathogens pp. 257-272. American Society of Microbiology.

36. Oliveira J, Castilho F, Cunha A, Pereira, MJ. 2012. Bacteriophage therapy as a bacterial control strategy in aquaculture. Aquac. Int. 20: $879-910$

37. Richards GP. 2014. Bacteriophage remediation of bacterial pathogens in aquaculture: a review of the technology. Bacteriophage 4: e975540.

38. Rao BM, Lalitha KV. 2015. Bacteriophages for aquaculture: are they beneficial or inimical. Aquaculture 437: 146-154.

39. Austin B, Austin DA. 1993. Bacterial Fish Pathogens: Diseases in Farmed and Wild Fish, 2nd Ed. London: Ellis Horwood.

40. McCarthy DH, Roberts RJ. 1980. Furunculosis of fish - the present state of our knowledge, pp. 293-341. In Droop MA, Jannasch HW (eds). Advances in Aquatic Microbiology, Academic Press, London.

41. Dallaire-Dufresne S, Tanaka KH, Trudel MV, Lafaille A, Charette SJ. 2014. Virulence, genomic features, and plasticity of Aeromonas salmonicida subsp. salmonicida, the causative agent of fish furunculosis. Vet. Microbiol. 169: 1-7.

42. Wiklund T, Dalsgaard I. 1998. Occurrence and significance of atypical Aeromonas salmonicida in non-salmonid and salmonid fish species: a review. Dis. Aquat. Organ. 32: 49-69.

43. Menanteau-Ledouble, S, Kumar, G, Saleh, M, El-Matbouli, M. 2016. Aeromonas salmonicida: updates on an old acquaintance. Dis. Aquat. Organ. 120: 49-68.

44. McCraw BM. 1952. Furunculosis of fish. US Fish Wildl. Serv., Special scientific report: Fisheries No 84: 1-87.

45. Griffin PJ, Snieszko SF, Friddle SB. 1953. A more comprehensive description of Bacterium salmonicida. Trans. Am. Fish. Soc. 82: 129-138.

46. Smith IW. 1963. The classification of "Bacterium salmonicida". J. Gen. Microbiol. 33: 263-274.

47. McCarthy DH. 1977. The identification and significance of atypical strains of Aeromonas salmonicida. Bull. Off. Int. Epiz. 87: 459463.

48. Popoff M. 1984. Genus III. Aeromonas. In: Bengey's manual of systematic bacteriology, Vol. 1. Williams and Wilkins, Baltimore, USA.

49. Austin DA, McIntosh D, Austin B. 1989. Taxonomy of fish associated Aeromonas spp., with the description of Aeromonas salmonicida subsp. smithia subsp. nov. Syst. Appl. Microbiol. 11:277-290.

50. Pavan M, Abbott S, Zorzopulos J, Janda J. 2000. Aeromonas salmonicida subsp. pectinolytica subsp. nov., a new pectinase-positive subspecies isolated from a heavily polluted river. Int. J. Syst. Evol. Microbiol. 50: 1119-1124.

51. Parte AC. 2014. LPSN-list of prokaryotic names with standing in nomenclature. Nucleic Acids Res. 42: (Database issue):D613-616.

52. Austin B, Austin DA, Dalsgaard I, Gudmundsdóttir BK, Høie S, Thornton JM, et al. 1998. Characterization of atypical Aeromonas salmonicida by different methods. Syst. Appl. Microbiol. 21: 50-64.

53. Garcia J, Larsen, J, Dalsgaard, I, Pedersen K. 2000. Pulsed-field gel electrophoresis analysis of Aeromonas salmonicida ssp. salmonicida. FEMS Microbiol. Lett. 190: 163-166.

54. O'hIci B, Olivier, G, Powell. R. 2000. Genetic diversity of the fish pathogen Aeromonas salmonicida demonstrated by random amplified polymorphic DNA and pulsed-field gel electrophoresis analyses. Dis. Aquat. Organ. 39: 109-119.

55. Martin-Carnahan A, Joseph SW. 2005. Aeromonadaceae. In: Bergey's manual of systematic bacteriology, 2nd Ed. Vol. 2. Springer. New York. USA.

56. Roger F, Marchandin H, Jumas-Bilak, E, Kodjo, A, Lamy, B, colBVH Study Group. (2012). Multilocus genetics to reconstruct aeromonad evolution. BMC Microbiol. 12: 62 .

57. Vincent AT, Trudel MV, Freschi L, Nagar V, Gagné-Thivierge, C, Levesque, RC, et al. 2016. Increasing genomic diversity and evidence of constrained lifestyle evolution due to insertion sequences in Aeromonas salmonicida. BMC Genomics 17: 44.

58. Pfeiffer F, Zamora-Lagos MA, Blettinger M, Yeroslaviz A, Dahl A, Gruber S, et al. 2018. The complete and fully assembled genome sequence of Aeromonas salmonicida subsp. pectinolytica and its comparative analysis with other Aeromonas species: investigation of the mobilome in environmental and pathogenic strains. BMC Genomics 19: 20.

59. Beaz-Hidalgo R, Hossain MJ, Liles MR, Figueras MJ. 2015. Strategies to avoid wrongly labelled genomes using as example the detected wrong taxonomic affiliation for Aeromonas genomes in the GenBank database. PLoS One 10: e0115813.

60. Han HJ, Kim DY, Kim WS, Kim CS, Jung SJ, Oh MJ, et al. 2011. Atypical Aeromonas salmonicida infection in the black rockfish, Sebastes schlegeli Hilgendorf, in Korea. J. Fish Dis. 34: 47-55.

61. Kim A, Nguyen, TL, Kim, DH. 2018. Complete genome sequence of the virulent Aeromonas salmonicida subsp. masoucida strain RFAS1. Genome Announc. 6: e00470-18. 
62. Beilstein F, Dreiseikelmann B. 2008. Temperate bacteriophage PhiO18P from an Aeromonas media isolate: characterization and complete genome sequence. Virology 373: 25-29.

63. Emond-Rheault JG, Vincent AT, Trudel MV, Brochu F, Boyle B, et al. 2015. Variants of a genomic island in Aeromonas salmonicida subsp. salmonicida link isolates with their geographical origins. Vet. Microbiol. 175: 68-76.

64. Vincent AT, Paquet VE, Bernatchez A, Tremblay DM, Moineau S, Charette SJ. 2017. Characterization and diversity of phages infecting Aeromonas salmonicida subsp. salmonicida. Sci. Rep. 7: 1-10.

65. Labrie SJ, Samson JE, Moineau S. 2010. Bacteriophage resistance mechanisms. Nat. Rev. Microbiol. 8: 317-327.

66. Ljungberg O, Johansson N. 1977. Epizootiological studies on atypical Aeromonas salmonicida infections of Salmonids in Swedish fish farms, 1967-1977. Bull. Off. Int. Epiz. 87: 475-478.

67. Hirvelä-Koski V. 2005. Fish pathogens Aeromonas salmonicida and Renibacterium salmoninarum: diagnostic and epidemiological aspects. Academic Dissertation, University of Helsinki.

68. Paterson, WD, Douey, D, Desautels D. 1980. Relationships between selected strains of typical and atypical Aeromonas salmonicida, Aeromonas hydrophila, and Haemophilus piscium. Can. J. Microbiol. 26: 588-598.

69. Herman RL. 1968. Fish furunculosis. Trans. Am. Fish. Soc. 97: 221-230.

70. Wood JW. 1967. Salmon disease report. Wash. Dept. Fish. Ann. Rep. 77: 111-112.

71. Inglis V, Yimer E, Bacon EJ, Ferguson S. 1993. Plasmid-mediated antibiotic resistance in Aeromonas salmonicida isolated from Atlantic salmon, Salmo salar L., in Scotland. J. Fish Dis. 16: 593-599.

72. McIntosh D, Cunningham M, Ji B, Fekete FA, Parry EM, Clark SE, et al. 2008. Transferable, multiple antibiotic and mercury resistance in Atlantic Canadian isolates of Aeromonas salmonicida subsp. salmonicida is associated with carriage of an IncA/C plasmid similar to the Salmonella enterica plasmid pSN254. J. Antimicrob. Chemother. 61: 1221-1228.

73. Kim YS, Yoon JW, Han HJ, Suebsing R, Kim JH. 2011. Prevalence and characterization of typical Aeromonas salmonicida chum salmon isolates in Korea. Fish Aquat. Sci. 14: 347-354.

74. DePaola A, Flynn PA, McPhearson RM, Levy SB. 1988. Phenotypic and genotypic characterization of tetracycline- and oxytetracycline-resistant Aeromonas hydrophila from cultured channel catfish (Ictalurus punctatus) and their environments. Appl. Environ. Microbiol. 54: 1861-1863.

75. Nawaz M, Sung K, Khan SA, Khan AA, Steele R. 2006. Biochemical and molecular characterization of tetracycline-resistant Aeromonas veronii isolates from catfish. Appl. Environ. Microbiol. 72: 6461-6466.

76. Furushita M, Shiba T, Maeda T, Yahata M, Kaneoka A, Takahashi Y, et al. 2003. Similarity of tetracycline resistance genes isolated from fish farm bacteria to those from clinical isolates. Appl. Environ. Microbiol. 69: 5336-5342.

77. Massicotte MA, Vincent AT, Schneider A, Paquet VE, Frenette M, Charette SJ. 2019. One Aeromonas salmonicida subsp. salmonicida isolate with a pAsa5 variant bearing antibiotic resistance and a pRAS3 variant making a link with a swine pathogen. Sci. Total Environ. 690: 313-320.

78. Alcaide E, Blasco MD, Esteve C. 2010. Mechanisms of quinolone resistance in Aeromonas species isolated from humans, water and eels. Res. Microbiol. 161: 40-45.

79. Jones BL, Wilcox MH. 1995. Aeromonas infections and their treatment. J. Antimicrob. Chemother. 35: 453-461.

80. Giraud E, Blanc G, Bouju-Albert A, Weill FX, Donnay-Moreno C. 2004. Mechanisms of quinolone resistance and clonal relationship among Aeromonas salmonicida strains isolated from reared fish with furunculosis. J. Med. Microbiol. 53: 895-901.

81. Varela AR, Nunes OC, Manaia CM. 2016. Quinolone resistant Aeromonas spp. as carriers and potential tracers of acquired antibiotic resistance in hospital and municipal wastewater. Sci. Total Environ. 542: 665-671.

82. Gutsell JS. 1948. The value of certain drugs, especially sulfa drugs, in the treatment of furunculosis in brook trout, Salvelinus fontinalis. Trans. Am. Fish. Soc. 75: 186-199.

83. Bullock GL, Stuckey HM, Chen PK. 1974. Corynebacterial kidney disease of salmonids: growth and serological studies on the causative bacterium. Appl. Microbiol. 28: 811-814.

84. Inglis V, Soliman M, Higuera Ciapara I, Richards R. 1992. Amoxycillin in the control of furunculosis in Atlantic salmon parr. Vet. Rec. 130: 45-48.

85. Stoffregen DA, Chako AJ, Backman S, Babish JG. 1993. Successful therapy of furunculosis in Atlantic salmon, Salmo salar L., using the fluoroquinolone antimicrobial agent enrofloxacin. J. Fish Dis. 16: 219-228.

86. Midtlyng PJ. 2014. Vaccination against furunculosis, pp. 185-199. In: Gudding R, Atle Lillehaug A, Evensen $\varnothing$ (eds.), Fish vaccination, John Wiley \& Sons, Chichester.

87. Lillehaug A, Lunder T, Poppe TT. 1992. Field testing of adjuvanted furunculosis vaccines in Atlantic salmon, Salmo salar L. J. Fish Dis. 15: 485-496.

88. Ellis AE. 1997. Immunization with bacterial antigens: furunculosis. Dev. Biol. Stand. 90: 107-116.

89. Midtlyng PJ. 1997. Vaccination against furunculosis, pp. 382-404. In: Bernoth EM, Ellis AE, Midtlyng PJ, Olivier G, Smith P (eds) Furunculosis: multidisciplinary fish disease research. Academic Press, San Diego, CA. USA.

90. Melingen GO, Wergeland HI. 2002. Physiological effects of an oil-adjuvanted vaccine on out-of-season Atlantic salmon (Salmo salar L.) smolt. Aquaculture 214: 397-409.

91. Koppang EO, Haugarvoll E, Hordvik I, Aune L, Poppe TT. 2005. Vaccine-associated granulomatous inflammation and melanin accumulation in Atlantic salmon, Salmo salar L., white muscle. J. Fish. Dis. 28: 13-22

92. Berg A, Rødseth OM, Hansen T. 2007. Fish size at vaccination influence the development of side-effects in Atlantic salmon (Salmo salar). Aquaculture 265: 9-15

93. Coscelli GA, Bermúdez R, Losada AP, Santos Y, Quiroga MI. 2015. Vaccination against Aeromonas salmonicida in turbot (Scophthalmus maximus L.): study of the efficacy, morphological changes and antigen distribution. Aquaculture 445: 22-32

94. Robertson PAW, O’Dowd C, Burrells C, Williams P, Austin B. 2000. Use of Carnobacterium sp. as a probiotic for Atlantic salmon (Salmo salar L.) and rainbow trout (Oncorhynchus mykiss, Walbaum). Aquaculture 185: 235-243.

95. Balcázar JL, Vendrell D, de Blas I, Ruiz-Zarzuela I, Múzquiz JL. 2009. Effect of Lactococcus lactis CLFP 100 and Leuconostoc mesenteroides CLFP 196 on Aeromonas salmonicida infection in brown trout (Salmo trutta). J. Mol. Microbiol. Biotechnol. 17: 153157.

96. Sica MG, Brugnoni LI, Marucci PL, Cubitto MA. 2012. Characterization of probiotic properties of lactic acid bacteria isolated from an estuarine environment for application in rainbow trout (Oncorhynchus mykiss, Walbaum) farming. Antonie Van Leeuwenhoek 101: 869-879.

97. Sahu MK, Swarnakumar NS, Sivakumar K, Thangaradjou T, Kannan L. 2008. Probiotics in aquaculture: importance and future perspectives. Indian. J. Microbiol. 48: 299-308.

98. Anderson DP, Siwicki AK. 1994. Duration of protection against Aeromonas salmonicida in brook trout immuno-stimulated with glucan or chitosan by injection or immersion. Prog. Fish-Cult. 56: 258-261.

99. Thomas J, Jerobin J, Seelan TSJ, Thanigaivel S, Vijaya-kumar S, Mukherjee A, Chandrasekaran N. 2013. Studies on pathogenecity of Aeromonas salmonicida in catfish Clarias batrachus and control measures by neem nanoemulsion. Aquaculture 396-399: 71-75.

100. Turker H, Yildırım AB. 2015. Screening for antibacterial activity of some Turkish plants against fish pathogens: a possible alternative in the treatment of bacterial infections. Biotechnol. Biotechnol. Equip. 29: 281-288. 
101. Starliper CE, Ketola HG, Noyes AD, Schill WB, Henson FG, Chalupnicki MA, et al. 2015. An investigation of the bactericidal activity of selected essential oils to Aeromonas spp. J. Adv. Res. 6: 89-97.

102. Ackermann, H. W. 2007. 5500 Phages examined in the electron microscope. Arch. Virol. 152: 227-243.

103. Suttle CA. 2005. Viruses in the sea. Nature 437: 356-361.

104. Calendar R. 2005. The Bacteriophages 2nd Ed. Oxford Univ. Press, New York.

105. d'Hérelle F. 1918. Technique de la recherche du microbe filtrant bactériophage (Bacteriophagum intestinale). C. R. Soc. Biol. 81: $1160-1162$

106. Bradley DE. 1967. Ultrastructure of bacteriophage and bacteriocins. Bacteriol. Rev. 31: 230-314.

107. Adams MJ, Lefkowitz EJ, King, AM, et al. 2017. 50 Years of the international committee on taxonomy of viruses: progress and prospects. Arch. Virol. 162: 1441-1446.

108. Chibani CM, Farr A, Klama S, Dietrich S, Liesegang H. 2019. Classifying the unclassified: a phage classification method. Viruses 11: 195.

109. Wheeler DL. 2000. Database resources of the national center for biotechnology information. Nucleic Acids Res. 28: 10-14.

110. Ackermann HW. 2009. Phage classification and characterization, pp.127-140. In Bacteriophages, Humana press.

111. Dion MB, Oechslin F, Moineau S. 2020. Phage diversity, genomics and phylogeny. Nat. Rev. Microbiol. 18: 125-138.

112. Krupovic M, Dutilh BE, Adriaenssens EM, et al. 2016. Taxonomy of prokaryotic viruses: update from the ICTV bacterial and archaeal viruses subcommittee. Arch. Virol. 161: 1095-1099.

113. Lefkowitz EJ, Dempsey DM, Hendrickson RC, Orton RJ, Siddell SG, Smith DB. 2018. Virus taxonomy: the database of the International Committee on Taxonomy of Viruses (ICTV). Nucleic Acids Res. 46(D1): D708-D717.

114. Adriaenssens EM, Sullivan MB, Knezevic P, et al. 2020. Taxonomy of prokaryotic viruses: 2018-2019 update from the ICTV Bacterial and Archaeal Viruses Subcommittee. Arch. Virol. 165: 1253-1260.

115. Simmonds P, Adams MJ, Benkő, M, et al. 2017. Consensus statement: virus taxonomy in the age of metagenomics. Nat. Rev. Microbiol. 15: 161-168.

116. Adriaenssens E, Brister JR. 2017. How to name and classify your phage: an informal guide. Viruses 9: 70.

117. Young R, Wang IN, Roof WD. 2000. Phages will out: strategies of host cell lysis. Trends Microbiol. 8: 120-128.

118. Brüssow H, Canchaya C, Hardt WD. 2004. Phages and the evolution of bacterial pathogens: from genomic rearrangements to lysogenic conversion. Microbiol. Mol. Biol. Rev. 68: 560-602.

119. Penadés JR, Chen J, Quiles-Puchalt N, Carpena N, Novick RP. 2015. Bacteriophage-mediated spread of bacterial virulence genes. Curr. Opin. Microbiol. 23: 171-178.

120. Merril CR, Scholl D, Adhya SL. 2003. The prospect for bacteriophage therapy in Western medicine. Nat. Rev. Drug Discov. 2: 489497.

121. Touchon M, de Sousa JAM, Rocha EP. 2017. Embracing the enemy: the diversification of microbial gene repertoires by phagemediated horizontal gene transfer. Curr. Opin. Microbiol. 38: 66-73.

122. Brown-Jaque M, Calero-Cáceres W, Muniesa M. 2015. Transfer of antibiotic-resistance genes via phage-related mobile elements. Plasmid 79: 1-7.

123. Stern A, Sorek R. 2011. The phage-host arms race: shaping the evolution of microbes. BioEssays 33: 43-51.

124. Shabbir MA, Hao H, Shabbir MZ, Wu Q, Sattar A, Yuan Z. 2016. Bacteria vs. bacteriophages: parallel evolution of immune arsenals. Front. Microbiol. 7: 1292.

125. Weinbauer MG. 2004. Ecology of prokaryotic viruses. FEMS Microbiol. Rev. 28: 127-181.

126. Sime-Ngando T. 2014. Environmental bacteriophages: viruses of microbes in aquatic ecosystems. Front. Microbiol. 5: 355.

127. Virgin HW. 2014. The virome in mammalian physiology and disease. Cell 157: 142-150.

128. Zablocki O, Adriaenssens EM, Cowan D. 2016. Diversity and ecology of viruses in hyperarid desert soils. Appl. Environ. Microbiol. 82: 770-777.

129. Freifelder DM. 1987. Microbial Genetics, Jones and Bartlett, Portolla Valley, CA

130. Weinbauer MG, Suttle CA. 1996. Potential significance of lysogeny to bacteriophage production and bacterial mortality in coastal waters of the gulf of Mexico. Appl. Environ. Microbiol. 62: 4374-4380.

131. Ackermann HW, DuBow MS.1987. Viruses of prokaryotes. CRC press.

132. Touchon M, Bernheim A, Rocha EP. 2016. Genetic and life-history traits associated with the distribution of prophages in bacteria. ISME J. 10: 2744-2754.

133. Howard-Varona C, Hargreaves KR, Abedon ST, Sullivan MB. 2017 Lysogeny in nature: mechanisms, impact and ecology of temperate phages. ISME J. 11: 1511-1520.

134. Almeida A, Cunha Â, Gomes NCM, Alves E, Costa L, Faustino MAF. 2009. Phage therapy and photodynamic therapy: low environmental impact approaches to inactivate microorganisms in fish farming plants. Mar. Drugs 7: 268-313.

135. Housby JN, Mann NH. 2009. Phage therapy. Drug Discov. Today 14: 536-540.

136. Alisky J, Iczkowski K, Rapoport A, Troitsky N. 1998. Bacteriophages show promise as antimicrobial agents. J. Infect. 36: 5-15.

137. Barrow P, Lovell M, Berchieri A. 1998. Use of lytic bacteriophage for control of experimental Escherichia coli septicemia and meningitis in chickens and calves. Clin. Diagn. Lab. Immunol. 5: 294-298.

138. Soothill JS. 1992. Treatment of experimental infections of mice with bacteriophages. J. Med. Microbiol. 37: 258-261.

139. Hagens S, Habel A, Ahsen U, Gabain A, Bläsi U. 2004. Therapy of experimental Pseudomonas infections with a nonreplicating genetically modified phage. Antimicrob. Agents Chemother. 48: 3817-3822.

140. Watanabe R, Matsumoto T, Sano G, Ishii Y, Tateda K, Sumiyama Y, et al. 2007. Efficacy of bacteriophage therapy against gut-derived sepsis caused by Pseudomonas aeruginosa in mice. Antimicrob. Agents Chemother. 51: 446-452.

141. Wills QF, Kerrigan C, Soothill JS. 2005. Experimental bacteriophage protection against Staphylococcus aureus abscesses in a rabbit model. Antimicrob. Agents Chemother. 49: 1220-1221.

142. Biswas B, Adhya S, Washart P, Paul B, Trostel AN, Powell B, et al. 2002. Bacteriophage therapy rescues mice bacteremic from a clinical isolate of vancomycin-resistant Enterococcus faecium. Infect. Immun. 70: 204-210.

143. Jado I, López R, García E, Fenoll A, Casal J, García P. 2003. Phage lytic enzymes as therapy for antibiotic-resistant Streptococcus pneumoniae infection in a murine sepsis model. J. Antimicrob. Chemother. 52: 967-973.

144. Cao J, Sun Y, Berglindh T, Mellgård B, Li Z, Mårdh B, et al. 2000. Helicobacter pylori-antigen-binding fragments expressed on the filamentous M13 phage prevent bacterial growth. Biochim. Biophys. Acta 1474: 107-113.

145. Fiorentin L, Vieira N, Barioni W. 2005. Use of lytic bacteriophages to reduce Salmonella enteritidis in experimentally contaminated chicken cuts. Rev. Bras. Cienc. Avic. 7: 255-260.

146. Toro H, Price SB, McKee S, Hoerr FJ, Krehling J, Perdue M, et al. 2005. Use of bacteriophages in combination with competitive exclusion to reduce Salmonella from infected chickens. Avian Dis. 49: 118-124.

147. Brüssow H. 2005. Phage therapy: the Escherichia coli experience. Microbiology 151: 2133-2140.

148. Vandenheuvel D, Lavigne R, Brüssow H. 2015. Bacteriophage therapy: advances in formulation strategies and human clinical trials. Ann. Rev. Virol. 2: 599-618. 
149. Goode D, Allen VM, Barrow PA. 2003. Reduction of experimental Salmonella and Campylobacter contamination of chicken skin by application of lytic bacteriophages. Appl. Environ. Microbiol. 69: 5032-5036.

150. Huff W, Huff G, Rath N, Balog J, Donoghue A. 2005. Alternatives to antibiotics: utilization of bacteriophage to treat colibacillosis and prevent foodborne pathogens. Poult. Sci. 84: 655-659.

151. Leverentz B, Conway WS, Alavidze Z, Janisiewicz WJ, Fuchs Y, Camp MJ, et al. 2001. Examination of bacteriophage as a biocontrol method for Salmonella on fresh-cut fruit: a model study. J. Food Prot. 64: 1116-1121.

152. Flaherty JE, Somodi GC, Jones JB, Harbaugh BK, Jackson LE. 2000. Control of bacterial spot on tomato in the greenhouse and field with H-mutant bacteriophages. Hort. Sci. 35: 882-884.

153. Withey S, Cartmell E, Avery LM, Stephenson T. 2005. Bacteriophages-potential for application in wastewater treatment processes. Sci. Total Environ. 339: 1-18.

154. Shao ZJ. 2001. Aquaculture pharmaceuticals and biologicals: current perspectives and future possibilities. Adv. Drug Deliv. Rev. 50: $229-243$.

155. Thornber, K, Verner-Jeffreys D, Hinchliffe S, Rahman MM, Bass D, Tyler CR. 2020. Evaluating antimicrobial resistance in the global shrimp industry. Rev. Aquac. (in press).

156. Park KH, Kato H, Nakai T, Muroga K. 1998. Phage typing of Lactococcus garvieae (formerly Enterococcus seriolicida) a pathogen of cultured yellowtail. Fisheries Sci. 64: 62-64.

157. Yamamoto A, Maegawa T. 2008. Phage typing of Edwardsiella tarda from eel farm and diseased eel. Aquac. Sci. 56: 611-612.

158. Bradley DE. 1965. The isolation and morphology of some new bacteriophages specific for Bacillus and Acetobacter species. J. Gen. Microbiol. 41: 233-241.

159. Ackermann HW, Dauguet C, Paterson WD, Popoff M, Rouf MA, Vieu JF. 1985. Aeromonas bacteriophages: reexamination and classification, pp. 175-199. In Annales de l'Institut Pasteur/Virologie (Vol. 136, No. 2). Elsevier, Masson.

160. Paterson WD, Douglas RJ, Grinyer I, McDermott LA. 1969. Isolation and preliminary characterization of some Aeromonas salmonicida bacteriophages. J. Fish Res. Can. 26: 629-632.

161. Wiebe WJ. Liston J. 1968. Isolation and characterization of a marine bacteriophage. Marine Biol. 1: 244-249.

162. Popoff M. 1971. Étude sur les Aeromonas salmonicida. II. Caractérisation des bactériophages actifs sur les Aeromonas salmonicida et lysotypie. Ann. Rech. Vét. 2: 33-45.

163. Ishiguro E, Kay W, Trust T. 1980. Temperate bacteriophages for Aeromonas salmonicida. FEMS Microbiol. Lett. 8: 247-250.

164. Ishiguro EE, Ainsworth T, Shaw DH, Kay WW, Trust TJ. 1983. A lipopolysaccharide-specific bacteriophage for Aeromonas salmonicida. Can. J. Microbiol. 29: 1458-1461.

165. Ishiguro E, Ainsworth T, Harkness R, Kay W, Trust T. 1984. A temperate bacteriophage specific for strains of Aeromonas salmonicida possessing A-layer, a cell surface virulence factor. Curr. Microbiol. 10: 199-202.

166. Rodgers CJ, Pringle JH, Mccarthy DH, Austin B. 1981. Quantitative and qualitative studies of Aeromonas salmonicida bacteriophage. J. Gen. Microbiol. 125: 335-345.

167. Ahne W, Capousek A, Popp W. 2000. Bacteriophage typing locates source and spread of Aeromonas salmonicida. Bull. Eur. Assoc. Fish Pathol. 20: 28-30.

168. Fauquet C, Mayo M, Maniloff J, Desselberger U, Ball A. 2005. Virus Taxonomy. pp. 35-85. VIIIth Report of the International Committee on Taxonomy of Viruses.

169. Petrov VM, Nolan JM, Bertrand C, Levy D, Desplats C, Krisch HM, et al. 2006. Plasticity of the gene functions for DNA replication in the T4-like phages. J. Mol. Biol. 361: 46-68.

170. Comeau AM, Bertrand C, Letarov A, Tetart F, Krisch HM. 2007. Modular architecture of the T4 phage superfamily: a conserved core genome and a plastic periphery. Virology 362: 384-396

171. Iranzo J, Krupovic M, Koonin EV. 2016. The double-stranded DNA virosphere as a modular hierarchical network of gene sharing. MBio 7: e00978-16.

172. Tetart F, Desplats C, Kutateladze M, Monod C, Ackermann HW, Krisch HM. 2001. Phylogeny of the major head and tail genes of the wide-ranging T4-type bacteriophages. J. Bacteriol. 183: 358-366.

173. Nolan J, Petrov V, Bertrand C, Krisch H, Karam J. 2006. Genetic diversity among five T4-like bacteriophages. Virol. J. 3: 30.

174. Lavigne R, Darius P, Summer EJ, Seto D, Mahadevan P, Nilsson AS, et al. 2009. Classification of Myoviridae bacteriophages using protein sequence similarity. BMC Microbiol. 9: 224.

175. Petrov VM, Ratnayaka S, Karam JD. 2010. Genetic insertions and diversification of the PolB-type DNA polymerase (gp43) of T4related phages. J. Mol. Biol. 395: 457-474.

176. Comeau AM, Tremblay D, Moineau S, Rattei T, Kushkina AI, Tovkach FI, et al. 2012. Phage morphology recapitulates phylogeny: the comparative genomics of a new group of myoviruses. PLoS One 7: e40102.

177. Kim JH, Son JS, Choi YJ, Choresca CH, Shin SP, Han JE, et al. 2012. Complete genomic sequence of a T4-like bacteriophage, phiAS4, infecting Aeromonas salmonicida subsp. salmonicida. Arch. Virol. 157: 391-395.

178. Kim JH, Son JS, Choi YJ, Choresca CH, Shin SP, Han JE, et al. 2012. Complete genome sequence and characterization of a broadhost range T4-like bacteriophage phiAS5 infecting Aeromonas salmonicida subsp. salmonicida. Vet. Microbiol. 157: 164-171.

179. Kim JH, Son JS, Choresca CH, Shin SP, Han JE, Jun JW, et al. 2012. Complete genome sequence of bacteriophage phiAS7, a T7-like virus that infects Aeromonas salmonicida subsp. salmonicida. J. Virol. 2894-2895.

180. Kim JH, Son JS, Choi YJ, Choresca CH, Shin SP, Han JE. et al. 2012. Isolation and characterization of a lytic Myoviridae bacteriophage PAS-1 with broad infectivity in Aeromonas salmonicida. Curr. Microbiol. 64: 418-426.

181. Vincent AT, Paquet VE, Bernatchez A, Tremblay DM, Moineau S, Charette SJ. 2017. Characterization and diversity of phages infecting Aeromonas salmonicida subsp. salmonicida. Sci. Rep. 7: 1-10.

182. Chen L, Yuan S, Liu Q, Mai G, Yang J, Deng D, et al. 2018. In vitro design and evaluation of phage cocktails against Aeromonas salmonicida. Front. Microbiol. 9: 1476.

183. Yang Z, Yuan S, Chen L, Liu Q, Zhang H, Ma Y, et al. 2018. Complete genome analysis of bacteriophage AsXd-1, a new member of the genus Hk97virus, family Siphoviridae. Arch. Virol. 163: 3195-3197.

184. Moreirinha C, Osório N, Pereira C, Simões S, Delgadillo I, Almeida A. 2018. Protein expression modifications in phage-resistant mutants of Aeromonas salmonicida after AS-A phage treatment. Antibiotics 7: 21.

185. Zhou Y. Yuan S. Yan T. Ma Y. 2019. Isolation and characterization of a novel lytic T4-like bacteriophage Asfd-1 infecting Aeromonas salmonicida. J. Integr. Technol. 8: 1-9.

186. Kavagutti VS, Andrei AŞ, Mehrshad M, Salcher MM, Ghai R. 2019. Phage-centric ecological interactions in aquatic ecosystems revealed through ultra-deep metagenomics. Microbiome 7: 1-15.

187. Chopyk J, Nasko DJ, Allard S, Callahan MT, Bui A, Ferelli AMC, et al. 2020. Metagenomic analysis of bacterial and viral assemblages from a freshwater creek and irrigated field reveals temporal and spatial dynamics. Sci. Total Environ. 706: 135395.

188. Bertozzi Silva J, Storms Z, Sauvageau D. 2016. Host receptors for bacteriophage adsorption. FEMS Microbiol. Lett. 363 : fnw002.

189. Paquet VE, Vincent AT, Moineau S, Charette SJ. 2019. Beyond the A-layer: adsorption of lipopolysaccharides and characterization of bacteriophage-insensitive mutants of Aeromonas salmonicida subsp. salmonicida. Mol. Microbiol. 112: 667-677. 
190. Wu JL, Lin HM, Jan L, Hsu YL, Chang LH. 1981. Biological control of fish bacterial pathogen, Aeromonas hydrophila, by bacteriophage AH 1. Fish Pathol. 15: 271-276.

191. Austin B, Austin DA. 1987. Bacterial fish pathogens: disease in farmed and wild fish, pp. 112-117. Ellis Horwood Ltd., Chichester, United Kingdom.

192. Verner-Jeffreys DW, Algoet M, Pond MJ, Virdee HK, Bagwell NJ, Roberts EG. 2007. Furunculosis in Atlantic salmon (Salmo salar L.) is not readily controllable by bacteriophage therapy. Aquaculture 270: 475-484.

193. Duarte J, Pereira C, Moreirinha C, Salvio R, Lopes A, Wang D, et al. 2018. New insights on phage efficacy to control Aeromonas salmonicida in aquaculture systems: an in vitro preliminary study. Aquaculture 495: 970-982.

194. Nikapitiya C, Dananjaya SHS, Chandrarathna HPSU, Senevirathne A, De Zoysa M, Lee J. 2019. Isolation and characterization of multidrug resistance Aeromonas salmonicida subsp. salmonicida and its infecting novel phage ASP-1 from goldfish (Carassius auratus). Indian J. Microbiol. 59: 161-170.

195. Fečkaninová A, Koščová J, Mudroňová D, Popelka P, Toropilova J. 2017. The use of probiotic bacteria against Aeromonas infections in salmonid aquaculture. Aquaculture 469: 1-8.

196. Expert Round Table on Acceptance and Re-Implementation of Bacteriophage Therapy. 2016. Silk route to the acceptance and re-implementation of bacteriophage therapy. Biotechnol. J. 11: 595-600.

197. Żaczek M, Łusiak-Szelachowska M, Jończyk-Matysiak E, Weber-Dąbrowska B, Międzybrodzki R, Owczarek B, et al. 2016. Antibody production in response to staphylococcal MS-1 phage cocktail in patients undergoing phage therapy. Front. Microbiol. 7: 1681.

198. O'Neill JG. 1979. The immune response of the brown trout, Salmo trutta, L. to MS2 bacteriophage: immunogen concentration and adjuvants. J. Fish Biol. 15: 237-248.

199. Kalatzis PG, Castillo D, Katharios P, Middelboe M. 2018. Bacteriophage interactions with marine pathogenic Vibrios: implications for phage therapy. Antibiotics 7: 15 .

200. Letchumanan V, Chan KG, Pusparajah P, Saokaew S, Duangjai A, Goh BH, et al. 2016. Insights into bacteriophage application in controlling Vibrio species. Front. Microbiol. 7: 1114.

201. Petrov VM, Ratnayaka S, Nolan JM, Miller ES, Karam JD. 2010. Genomes of the T4-related bacteriophages as windows on microbial genome evolution. Virol. J. 7: 292. 